\title{
Belgeo
}

Revue belge de géographie

4 | 2017

La Belgique : quelques nouveaux regards sur un pays

en forte mutation - Belgium: some new looks at a

higly evolving country

\section{Financialization within the contemporary economic geography of Belgium}

Jannes Van Loon

\section{(2) OpenEdition}

Electronic version

URL: http://journals.openedition.org/belgeo/20880

DOI: $10.4000 /$ belgeo.20880

ISSN: 2294-9135

Publisher:

National Committee of Geography of Belgium, Société Royale Belge de Géographie

\section{Electronic reference}

Jannes Van Loon, «Financialization within the contemporary economic geography of Belgium », Belgeo [Online], 4 | 2017, Online since 12 April 2018, connection on 01 May 2019. URL : http:// journals.openedition.org/belgeo/20880; DOI : 10.4000/belgeo.20880

This text was automatically generated on 1 May 2019.

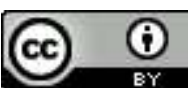

Belgeo est mis à disposition selon les termes de la licence Creative Commons Attribution 4.0 International. 


\title{
Financialization within the contemporary economic geography of Belgium
}

\author{
Jannes Van Loon
}

This work was supported by the European Research Council [grantnumber313376].

\section{Introduction}

1 In 2007 the global financial system almost came to a standstill. In the following years states all across the Western world 'saved' their financial systems first through rescuing domestic banks with trillions of euros and dollars in state support and guarantees, and then through loose monetary policies aiming to spur debt-fueled economic recovery. Belgium, with its large, internationally orientated domestic banks, experienced similar problems. Two of the three largest Belgian commercial banks: Fortis and Dexia had not only become true global players with international assets of respectively EUR674 billion and EUR567 billion late 2006, they also had made highly leveraging their activities through interbank lending crucial for the realization of their ambitious growth models (Ardaen, 2012; Chang and Jones, 2013; Depuydt, 2010). Once global capital halted Belgian banks experienced enormous losses and Fortis and Dexia were nationalized. Moreover, as part of the Eurozone, Belgium followed the general cure for the Great Financial Crisis (hereafter GFC) prescribed by the European Central Bank of quantitative easing and low interest rates stimulating a debt-fueled recovery especially through stimulating trade in financial assets on financial markets and capital intensive activities such as real estate markets. Although Belgium had a shared 'European experience' with the crash of its stock markets and banking sector, the GFC did not set in motion the steep and deep economic crisis that so many other European countries experienced.

In countries were the GFC has had a more devastating effect, critical geographers have turned their attention towards finance (e.g., Engelen, 2008; Pike and Pollard, 2009). For them, the credit crunch that has caused the GFC revealed a toxic link between financial 
practices and the built environment, in essence, it revealed how financial actors are deeply motivated to liquefy illiquid assets such as real estate to further enlarge the financial sphere (Aalbers, 2012). These scholars conceptualize the rise, and fall or further intensification (?), of global finance as a structural transformation within capitalism, as a move towards 'financialized capitalism' (Aalbers, 2017; Lapavitsas, 2009; van der Zwan, 2014). The origination of financialized capitalism relates to the breakdown of Bretton Woods in the 1970s and waves of financial liberalization and reregulation combined with digitalization, making finance much more footloose (French et al., 2011; Pryke and Allen, 2000). As a result, the size of financial markets and influence of financial actors on political economies increased rapidly into historically unprecedented dimensions (Lapavitsas, 2009; Hardie and Howarth, 2013; Fernandez and Aalbers, 2016). A rich body of work has demonstrated empirically how financial actors and financial logics increasingly shape practices in four actors that are important for the functioning of political economies: non-financial corporations (Krippner, 2005), households (Martin, 2002), the state (Hendrikse, 2015) and finance itself (Hardie and Howarth, 2013; Harmes, 1998) thereby reshaping domestic political economies.

3 As a relatively recent phenomenon the rise of financialized capitalism is shaped by context specific elements such as the specific character of domestic institutions, politics and corporations that steer an economy. Therefore, capitalism is looked at as 'variegated' in the sense that it is not only driven by tendencies within global capitalism towards convergence such as the rise of global finance and the continuous pressure to create new (financial) markets. But, variegation also points to how these general tendencies are shaped by historic economic geographies into local specificities (Brenner et al., 2010; Dixon, 2011).

4 This brings us back to Belgium. Belgian geographers have developed an extremely rich scholarship on how socio-economic, geographical conditions morph capitalism in a specific, Belgian shape, not only through rich studies on firm localization, regionalization and path dependence (Kesteloot and De Maesschalck, 2001; Oosterlynck, 2010; Vanneste and Cabus, 2007; Vanthillo and Verhetsel, 2012), but, also through drawing rich historic geographies of financial actors, for instance showing the strong role of Francophone finance (e.g., Société Générale) in ordering Belgian economic space (Buyst, 2011; Kesteloot and De Maesschalck, 2001; Oosterlynck, 2007; Saey et al., 1988). It is no accident that the crucial term 'glocalisation' - that investigates how global capitalism morphs into specific localities - was coined by the Belgian geographer Swyngedouw (1992). However, although a couple of Belgian geographers play important roles in international debates on the rise of global finance (Bassens et al., 2013; Bassens and van Meeteren, 2014; Fernandez et al., 2016; Gonzalez and Oosterlynck, 2014), scholarship on how finance shapes Belgium's current economic geography are scarce. There is some recent work on financialization processes related to Brussels, to its Airport (Deruytter and Derudder, 2015) and housing production (Romainville, 2017), but, to the author's knowledge, there are no comprehensive analyses at the national scale. Moreover, in contemporary Belgian economic geography debates often take place in a parallel way: in separate conference sessions and publications in French - more focused on Brussels and Wallonia - and Dutch/English - more focused on Brussels and Flanders. Accordingly, the French literature is less accessible and connected to financialization scholars that tend to publish in English as the phenomenon originates from Anglo American countries. 
Thus, in general, Belgian geographers seem, despite the great financial consequences of the nationalization of Dexia and Fortis, not to be that interested in researching how the rise of financialized capitalism shapes the Belgian economic geography. A reason could be that financialization processes do not appear in Belgium. Indeed, van Loon (2016, 2017ab) shows that - compared to a highly financialized case as the Netherland - Belgian urban development and real estate markets have proven to be rather 'protected' against the rise of financialized capitalism. However, either as a possible 'negative case' of financialization showing that the rise of financialized capitalism is not universal and ubiquitous across the West (cf. Christophers, 2015), or as a further expansion of the financialization debate to Western countries, we are in dire need to take finance more seriously into our thinking about the Belgian economic geography.

6 This paper first discusses in more depth the four actors that are crucial in facilitating the rise of financialized capitalism. This enables to offer a first, tentative, quantitative exploration of the balance sheets of these four actors. Brought in conversation with the existing literature, this allows to present ideas for further research on how processes of financialization could relate to the contemporary economic geography of Belgium.

\section{The rise of financialized capitalism}

7 As briefly discussed above, one way of looking at the rise of financialized capitalism is through analysing how 'financial actors, markets, practices, measurements and narratives' (Aalbers, 2017, p. 3) have become dominant among crucial actors of political economies, namely non-financial firms (hereafter NFCs), financial institutions, states and households. The financialization literature shows that this dominance leads to a structural transformation of practices within these actors and, consequently, especially in Anglo-American countries, to a transformation of domestic political economies and related economic geographies. Accordingly, there is a booming literature on the financial geography of this change (Bassens and van Meeteren, 2014; Engelen, 2008; French et al., 2011; Wojcik, 2012). However, financialization is a multilayered and multiscalar process (cf., van Loon, 2016) and plays out, as discussed below, differently in each actor.

8 The first actor, the financialization of corporations relates to a transformation of business models, a qualitative shift whereby the adoption of financial logics prioritizes a focus on financial profitability over productive investments and long-term growth. Put differently, 'profit-making occurs increasingly through financial channels rather than through trade and commodity production' (Krippner, 2005, p. 181). For example, a car manufacturing becoming a securitisation machine of car loans. As a consequence, leveraged growth, for instance through mergers and acquisitions, financial assets and complex financial instruments such as derivatives become central to business models that aim to boost a corporation's value, e.g., reflected through high stock market capitalization (Froud et al., 2006; Pike and Pollard, 2009).

9 Second, the financialization of households relates to two developments. First, many states replaced government lending to stimulate the domestic economy with mortgage production. In this privatised Keynesianism continuous mortgage-debt production has to accelerate booms on housing markets boosting consumer confidence and subsequently real spending so domestic economies could thrive (Fernandez and Aalbers, 2016). However, the extreme relaxation of mortgage conditions in the United States also 
spurred a pyramiding of low quality debt giving birth to an almost meltdown of the global financial system (Aalbers, 2012). Second, there is a shift observable within Western countries whereby the state retreats from the provision of public goods (Martin, 2002). Households are increasingly responsible to manage their own funds to provide themselves for schooling, health care, and pensions often allocating this task to institutional investors whose power has increased tremendously (Dixon and Monk, 2014; Martin, 2002).

Third, recent studies show how different state agencies interact with this new era of financialized capitalism. There is a wealth of empirical case studies showing how local and national state debt has opened up to financialization tools (Hendrikse, 2015; Lagna, 2015; Weber, 2010). Usually, this involves replacing traditional forms of debt, i.e., bonds, with more complex forms such as derivatives, collateralized debt obligations and tax increment financing, often promising lower debt costs or more attractive debt levels but in reality often creating badly understood financial risks that can accumulate into sizeable financial losses. But, waves of privatization and financialization have also removed the barriers between public good provisions - such as infrastructure - and predatory finance (Allen and Pryke, 2013; Peck and Whiteside, 2016). Consequently, roads have become financial investments and water provision a tool for complex debt generation. Therefore, on the one hand financialization of the state relates to opportunistic financial behavior: 'how governments [i.e., state agencies] wield the market-based practices and technologies of financial innovation to pursue statecraft objectives' (Lagna, 2015, p. 1). On the other hand, state agencies become "'entangled" (Ashton et al., 2016) with financial actors in often badly understood ways altering sociolegal arrangements and policies to accelerate the circulation of capital, revalorise space, and increase market liquidity... [financialization] close[s] off... public debate on alternative courses... based on, for example, public investment, social redistribution, and social justice' (Gotham, 2014, p. 19).

11 Fourth, the financialization of financial institutions relates to a couple of developments. First, a tendency has been observed whereby banks in many countries started to loosen their long-term relations with corporations as banks adopted market-oriented business models based on inter-bank borrowing bypassing depositors as main providers of money. The creation of growing debt and its trade through global capital markets created large financial markets and turned finance into an important source of profit (Hardie and Howarth, 2013). In this regard, housing related debt has become a crucial element of both banking activities and the functioning of financial systems whereby residential real estate is conceptualized as crucial collateral (Aalbers et al., 2012; Fernandez and Aalbers, 2016). In addition, banks started to develop or expand investment banking activities, making trading in listed and non-listed firms an important part of their business strategies (Wojcik, 2012; Lapavitsas and Powell, 2013), i.e., exemplifying the rise of financial markets for their own good' (Aalbers, 2008, p. 149).

Second, as many households have delegated the management of their rising stocks of financial assets to investment funds, pension funds and insurers, the managers of these funds, institutional investors, have become important actors in global finance (Dixon and Monk, 2014). As conventional assets as bonds and securities cannot absorb the influx of institutional money (Fernandez and Aalbers, 2016), there is pressure on all kinds of 'raw materials', such as non-listed firms (Froud et al., 2006), real estate (van Loon and Aalbers, 2017), and infrastructure (Ashton et al., 2016), to be transformed into financial, tradable 
assets. Taken together, the literature on the financialization of financial institutions illustrates how 'finance is increasingly becoming "decoupled from production to become an independent power, an autocrat over the real economy"' (Cox in Aalbers, 2008, p. 149).

In conclusion, the ways in which financialization takes place differs throughout the various actors, but, where financialization processes structurally change a political economy scholars label it as a new era of capitalism: financialized capitalism (Aalbers, 2017; Lapavitsas, 2009; van der Zwan, 2014). However, this rise of financialization processes has not received proper attention among Belgian geographers yet. Therefore, the next section quantitatively explores - in a tentative and not empirical way - if the realm for financialization processes has increased in Belgium.

\section{A tentative, quantitative exploration: balance sheets as heuristic device}

The discussion above indicates that within the four dimensions of the Belgian political economy (i.e., households, state, banks and NFCs) opportunities for financialization processes could have increased considerably. This section offers a tentative, first attempt to signal if the realm for financialization processes has increased in Belgium. For doing so, OECD-data is available that allows to compose consolidated financial balance sheets of these four actors starting in the mid-1990s. Using consolidated accounts removes the 'double counting' of the financial assets and liabilities of sub-actors or sub-units. To assess the increase relative to the entire economy over time assets and liabilities are expressed as percentage of GDP. To balance out extreme years the data is ordered through 4-year averages. Periods are chosen according the following logics: first data available (period I), the rapid expansion of finance in the build up to the GFC (period II), latest data available/GFC (period III) (cf. Ward et al., n.d.) ${ }^{1}$.

The resulting Figure 1 can be seen as a heuristic device that allows a quantitative screening of the changing importance of finance reflected to the increase of financial assets and liabilities since the mid-1990s. Stylistically, the discussion of these balance sheets in the subsequent section is ordered through the four different actors. However, it is crucial to acknowledge that these actors are interconnected and that the balance sheet should thus be seen as a device to generate venues for future research. As such, in this paper the balance sheet is not used as a research method for empirical, quantitative analyses but as a device to create a first, tentative 'screening' of possible changes in the Belgian economy. A more thorough and robust quantitative analysis inspired by for instance the work of Anderson et al. (2014), Ertürk et al. (2005) and McKenzie (2013) would be very welcome. Moreover, the balance sheet offers a first, tentative quantitative screening, it does not offers insights on, for instance, the concentration of assets and liabilities within an actor. For example, although households could look very wealthy, financial wealth could be concentrated among a select group of people. Neither do the balance sheets offer information about the motives of the holders of these assets and liabilities and their geography. Nonetheless, combined with relevant academic literature the balance sheets do create some interesting insights into the rise of finance within the Belgian political economy. 
Figure 1. Belgium: financial assets \& liabilities-to-GDP first data available $(1,1992-1995)$ pre-GFC $(2,2004-2007)$ post-GFC $(3,2009-2012), 4$ year averages.

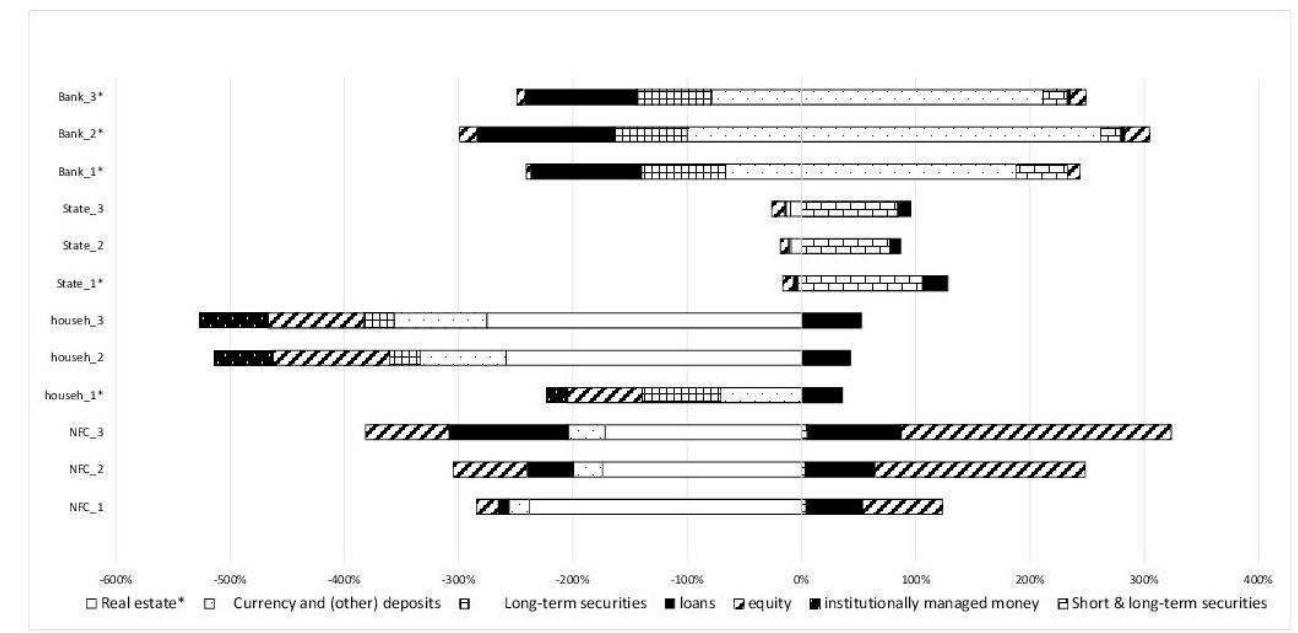

* NO dATA TO gIVE INDICATION FOR REAL ESTATE VALUES

SOURCES: POULLET (2013); EUROSTAT (2016); OECD (2016)

\section{The balance sheet of the Belgian political economy: a research agenda}

Belgium has, compared to other European countries, a high ratio of both financial assets and liabilities to GDP (Brown et al., 2014). Figure 1 clearly shows that since the mid-1990s and despite the GFC, in all actors, except the Belgian banks, financial assets and liabilities have increased stronger than the real economy (i.e., GDP). Also, this stretching of balance sheets made financial assets roughly 7.5 times larger than Belgian GDP. This confirms that - in line with general developments described in the financialization literature - finance has become a crucial element of the Belgian political economy suggesting that the potential realm for financialization processes has expanded. However, there are only a few academic studies explaining if and, if so, how this stretching of balance sheets has enabled financialization processes (e.g., Deruytter and Derudder 2015; Romainville, 2017).

\section{Non-Financial Corporations (NFCs)}

17 Many NFCs in Belgium receive sizeable equity capital from wealthy Belgian households who aim to grow their multi-generational wealth in a slow, low-risk manner. This creates an important barrier to processes of financialization as they tend to use their controlling stakes to set business strategies around predictable results, cost efficiency and risk minimization. Patient capital fed firms resist both high levels of external capital therefore they have a relatively low share of loans on their balance sheets - and complex financial products as it decreases their influence vis-à-vis financial actors. Outsiders are further kept away by opaque corporate governance that blurs the lines between owners, directors and managers, but also put a focus on non-financial gains central and these corporations usually remain relatively small and domestically-oriented (Daems, 1998; van Loon, 2016, 2017; Molly et al., 2012). 

financialization within the real estate sector, the dramatic increase of both financial assets and liabilities between the pre-financialization and pre-GFC period shown in Figure 1 suggests an increased realm for financialization processes in other sectors. Financial assets that indicate an increase of mergers and acquisitions as well as an increase of a focus on financial gains - e.g., (un)quoted shares and loans - have increased considerably. On the one hand this could be in line with the concept of patient capital which is often provided through equity and debt (Deeg et al., 2016). However, a case as the listed Ab Inbev that rapidly grew through aggressively leveraged mergers and acquisitions into the largest brewery of the world begs for further research especially as, to the author's knowledge, no case studies on the financialization of Belgian firm(s) have been published yet. In this regard, work of Lehrer and Celo (2016) - who show a processes of 'bifurcation' whereby highly financialized and patient-capital fed firms in Germany co-exist - could be an inspirational starting point to enrich our ideas about the role of financialization processes within the economic geography of Belgium.

\section{Households}

Belgian households are among the wealthiest in the world managing conservative household portfolios of savings ('other deposits' in Figure 1), equity in listed and nonlisted firms, securities and, in particular low-leveraged residential real estate. Before 2007 household's financial assets grew steadily and included long-held equity in Belgian firms as well as domestically-oriented investments in assets that were perceived as safe: i.e., Belgian state bonds, and shares in Belgian banks and REITs. Consequently, the financial crisis hit individual households through their investments in Belgian finance and the downturn in equity markets. But, also during the GFC through the ECB's low-interest rate monetary policy making returns on saving accounts very low.

This large amount of less risk full assets (cf. Ertürk et al., 2005) managed by households themselves could be an indication for the existence of large stocks of family capital. This multi-generational wealth looking for sustainable growth is an important type of patient capital that can function as a barrier to financialization processes (Lehrer and Celo, 2016; Deeg et al., 2016): to a certain extent, it protects household portfolios from the volatility of financial markets

21 Although pensions are mainly provided by the state through a pay-as-you go system recent reforms combined with an increased sense that the state will not meet all future financial obligations have made self-funded pension schemes more popular (Naczyk, 2012). Hence, there was a strong increase in institutional managed assets (see Figure 1) indicating a more powerful role for institutional investors within the Belgian political economy. This opens up an interesting realm for future research, for instance, to develop geographies of these institutionally managed investment portfolios. The literature suggests that this would lead to the internationalization of household's investment portfolios and shift towards more risky asset categories (Ertürk et al., 2005; Harmes, 1998; van Loon and Aalbers, 2017).

Belgian household debt did not expand in a manner comparable to many other Western countries (cf. Fernandez and Aalbers, 2016). The steadily increasing debt of Belgian households consists mostly of mortgages but despite the steady and strong increase of property prices and related rise of real estate values the debt-to-GDP ratio is still rather 
low. This relates to a deep culture of housing self-provision in which self-building creates unique suburban properties putting the desires of the resident (as opposed to market considerations) central, resulting in households who tend to stay put (Kesteloot and Maesschalck, 2001; Vanneste and Cabus, 2007). However, where in the past cheap land and relax planning regulation spurred this model increased land scarcity and stricter planning rules has put pressure on this housing model due to rising land costs. Increasing residential real estate prices has been further spurred by an increased willingness of banks that started securitisation programmes to borrow, low interest rates and policy changes making interest rates partly deducible, making housing less affordable and giving rise to more urban forms or residential real estate (Damen et al., 2014; Winters and van den Broeck, 2016; Romainville, 2017). This makes it quite likely that especially among first time home buyers and in specific, more expensive, urban areas processes of financialization could be observed, for instance exemplified through high loan-to-values.

\section{State agencies}

Belgium's corporatist political system was based on pillars, religious or ideological organizations that encompassed all spheres of life. It underwent a process of regionalization in the 1970s, setting in motion the division of the three main parties into Dutch and French speaking branches that over time became autonomous organizations. Public responsibilities and related bureaucracies were transferred to Flanders, Wallonia and Brussels in successive waves of regionalization, creating more pronounced divergence in their pathways even as these regions still had to cooperate on many issues. Finding such multiscalar compromises is an often time-consuming and deadlocked process, so that economic restructuring have been ameliorated as employers' organization, labour unions and other corporatist structures organization structures still play a prominent role in the current devolved state model (Moulaert and Willekens, 1985; Oosterlynck, 2010; Saey et al., 1988; Vanthillo and Verhetsel, 2012).

The politics behind this re-configuration of the state resulted in the institutionalization of the 'double' compensation measure meaning that an investment into one region or religion should have an equivalent in the other and until the late 1980s these regionalizing policies were embedded in an extensive welfare system and generous subsidies and investments (see Figure 1 assets equity in/loans to) to support national sectors as result of the strong unions and industrial interests (Moulaert and Willekens, 1985; Oosterlynck, 2010). As a result, the Belgian state was heavily indebted in the early 1990s (Figure 1) and had to find creative solutions to show it was willing to meet the Maastricht criteria of state debt below $60 \%$ (though it never has).

Attempted solutions to this revolved in a slow pace. They took the form of austerity and the privatisation of state-owned financial institutions, corporations (particularly telecoms and energy), and state investment funds: although state agencies often remained important shareholders within these 'privatised' organizations. Another solution was found through the adoption of public private partnerships, particularly for infrastructure projects. This funding structure for a while allowed the state to keep the expenditure to be kept off-balance sheets and, for the same reason, the Belgian state also increasingly adopted complex financial instruments such as derivatives from the 1990s onwards. 

how PPP-structures, that are imported from an Anglo-American realm, often are in conflict with the existing institutional context. This centres our attention to how linkages between state agencies and financial actors can change over time, and it would be extremely interesting to put, in line with the international literature (Allen and Pryke, 2013), the financial dimension into this research area. A study that has done this, Deruytter and Derudder (2015), shows how the sale of Brussels Airport to an AngloAmerican investment fund has transformed a former 'public good' into a financial asset.

As discussed above, Belgian banks needed heavy state support during the crisis therefore increasing state debt and making the state a large owner in state firms again. In 2016, the Belgian state still owns the bank/insurer Belfius (with 176 billion euro of liabilities) and provides 61 billion euro in guarantees for Dexia. But, there are also structural elements that make the Belgian state heavily indebted such as a pay-as-you-go pension fund system combined with an ageing population, an expansive state apparatus and structural tax avoidance.

However, whereas a more structural exploration about how central and regional state agencies relate to financialization processes is still lacking, a recent study focussing on urban development in Flanders (van Loon, 2017a) shows that Flemish municipalities have a long history of financial autonomy and financial experimentation has been much more pronounced in the past. In general, Flemish municipalities do not have complex financial instruments and operate with low and decreasing debt-to-income levels making it hard to observe the rise of 'predatory finance' (Peck and Whiteside, 2016).

\section{Financial institutions: banks}

29 High household saving rates created a reservoir of deposits that could be used as engine for opportunistic commercial banking growth. Traditionally, public credit agencies played a pivotal role in the management of these deposits using them primarily to provide conservative loans against low interest rates. During a wave of privatisation in the 1990s the public credit agencies merged and the deposits became concentrated within three listed Belgian banks who all had ambitious growth models to which interbank lending became crucial (Depuydt, 2010; Ardaen, 2012). Fees and commissions became much more important to the banks' business models than interest margins on loans and deposits, and in this period, as Figure 1 shows, banks' assets and liabilities grew rapidly. Enabled by financial liberalisation and lax supervision deposits and current account surpluses were now used as collateral for leveraged growth thereby making extensive use of shadow banking businesses to attain credit from global financial markets via structured debt securities with the implication that concentrated geographical risks particularly from countries with housing booms - were imported onto the balance sheets of Belgian banks (Chang and Jones, 2013). As a result of these structural changes to the Belgian banking industry and the shift in their business models, the portion of 'safe' core tier 1 capital (i.e., cash and transferable deposits in Figure 1) severely decreased up to 2007.

Belgian banks' reliance on global capital markets through inter-bank lending left them vulnerable to the financial crisis and in 2008 they suffered enormous losses mostly as the result of write-downs on financial assets (Chang and Jones, 2013). The Belgium state supported KBC and nationalised Dexia and Fortis that it later sold to French BNPparibas, 
partially reversing the banking system's privatisation and reversing the growth in the bank's balance sheets. The most significant factor in this is the sale of a significant portion of the bank Dexia's assets following its nationalisation. In this process of deleveraging banks also decreased their lending to corporations, reflected in the decrease short and long term loans on asset side of Figure 1. The financialization exemplified to the switch towards market oriented banking has been described in detail. However, the connections towards other actors remain under-studied: how does the financialization of Belgian banks related to NFCs from other actors then real estate? For instance, did/do Belgian banks also push for the rise of housing finance? And, more general, how has the shift towards market based banking changed the role of banks shaping the economic geography of Belgium?

\section{Financialization and Belgian economic geography?}

As argued above, this century Belgian geographers have been focused much on both the historic geography of finance (Buyst, 2011; Kesteloot and Maesschalck, 2001; Oosterlynck, 2007, 2010) and the rise of global finance (Bassens et al., 2013; Fernandez et al., 2016; Gonzalez and Oosterlynck, 2014). Consequently, there is a rich understanding on how finance shaped the economic geography of Belgium and Belgian scholars have contributed to important, international debates. However, the role that contemporary 'financialized' finance (cf. Van Loon and Aalbers, 2017) plays, not only as regular facilitator of all kinds of socio-spatial processes, but, more importantly, increasingly as a dominant force that aims to penetrate all kinds of actors and spaces to extract financial profits from has remained under-studied in the Belgian context. This neglect leads to an odd situation in which the financial balance sheets of all four important actors of the Belgian political economy have stretched widely, indicating that there could have been fertile ground for financialization processes to take off. But, as case studies that investigate the (non-)originating of financialization process are lacking, the effects of this enlargement of Belgian finance remain under-studied.

To overcome this, Table 1 summarizes the discussion above and presents ideas for future research on financialization in Belgium. Table 1 should not be looked at as a fixed research agenda but more as a device to trigger debate and inspiration for future research projects. Also, as financialization relates to multilayered and multiscalar process the '(non-)financialization' of a certain case does not automatically indicates the (non)financialization of an entire actor. Table 1 thus points to the following research directions that could help to map out the presence of financialization within the Belgian context:

NFCs: it is crucial to further investigate the workings of patient capital in other sectors than real estate but also to analyse firms that have probably financialized. If cases of financialization can be proven then it would be interesting to analyse how financialized and patient capital fed firms co-exist. For instance through mapping out the localization patterns of different types of firms to see if, for instance, financialized firms are more inclined to still concentrate around 'Francophone' capital and (global) financial markets located in Brussels.

Households: the balance sheets have stretched considerably indicating the need to research the rise of housing finance (especially among first time house buyers and/or in rapidly gentrifying areas) and the rise of institutionally managed households portfolio's. 
The quantitative data also suggests that the aggregated assets and liabilities of Belgian households have become more tied to global capital markets and shifted to 'riskier' investment categories.

State agencies: international scholarship points to at least two interesting research venues. The first is 'entanglement' (Ashton et al., 2016) through the adoption of complex financial instruments or high levels of debt. A first screening at the Flemish municipal level did not find such a trend in recent decades but did point to interesting more historic research periods. Antwerp, for instance, came close to bankruptcy in the 1980s as the result of, among other things, rather opportunistic financial innovation such as redemption free municipal bonds (van Loon, Oosterlynck and Aalbers, n.d.). However, more thorough indepth studies focusing (also) on other regions and other state agencies could be interesting (see Deruytter, 2016), especially when the focus is on entities that use much external finance to fund growth ambitions or entities that have to deal with financial constraints. In this regard, also the central state should be studied: has the Belgian state, in line with other European countries (cf. Lagna, 2015), turned to financial innovation to answer demands from the European Commission? The second is privatisation opening (semi-)public organizations up for financialization processes through comparable processes as within NFCs thus offering a probably third interesting category in mapping localisation patterns.

Banks: there is some popular and academic work showing clearly the financialization - or the more market orientated behaviour - of Belgian banks. However, what remains understudied is the relationship between these financialized banks and other economic sectors and geographies. In the real estate sector, for instance, patient capital proved to be a strong barrier shielding Belgian real estate firms for financialization processes (van Loon, 2016).

In conclusion, this paper offers a first exploration on the existence of financialization processes within the Belgian political economy. Consequently, future studies can help to map these processes further. A great challenge for doing so is to integrate the French, Dutch and English literature on economic geography and finance in Belgium and also to conduct more historical studies. 
Table 1. Studying financialisation in Belgium to develop a 'new' Belgian economic geography.

\begin{tabular}{|c|c|c|c|}
\hline Actor & $\begin{array}{l}\text { Financialization processes } \\
\text { observed } \\
\text { in literature }\end{array}$ & $\begin{array}{l}\text { Published Belgian cases pro } \\
\text { and contra financialization }\end{array}$ & Most likely cases in Belgium \\
\hline $\begin{array}{l}\text { Non Financial } \\
\text { Corporations }\end{array}$ & Financialization of a firm & Contra: real estate NFCs & $\begin{array}{l}\text { Large multinationals rapidly } \\
\text { growing: e.g., Ab Inbev } \\
\text { SMEs through derivatives, } \\
\text { more historical cases }\end{array}$ \\
\hline \multirow[t]{2}{*}{ Households } & Rise of housing finance & None & $\begin{array}{l}\text { First time house-buyers and } \\
\text { areas with rapid house price } \\
\text { increases }\end{array}$ \\
\hline & $\begin{array}{l}\text { Rise of institutional } \\
\text { investors }\end{array}$ & None & $\begin{array}{l}\text { Rapidly growing domestic } \\
\text { linstitutional Investors: e.g., AG }\end{array}$ \\
\hline \multirow[t]{2}{*}{ State agencies } & $\begin{array}{l}\text { 'entanglement'/financial } \\
\text { 'innovation' }\end{array}$ & $\begin{array}{l}\text { Contra: municipal } \\
\text { involvement in urban } \\
\text { development (Flanders) }\end{array}$ & $\begin{array}{l}\text { National and regional state } \\
\text { Municipalities with financial } \\
\text { constrains or ambitious growth } \\
\text { plans }\end{array}$ \\
\hline & $\begin{array}{l}\text { Privatisation opening up } \\
\text { (former) state entities for } \\
\text { finance }\end{array}$ & Pro: Brussels Airport & (semi-)privatised organizations \\
\hline $\begin{array}{l}\text { Financial } \\
\text { institutions: banks }\end{array}$ & $\begin{array}{l}\text { Turn towards market } \\
\text { oriented banking }\end{array}$ & Pro: major Belgian banks & $\begin{array}{l}\text { Fortis, Dexia and to a lesser } \\
\text { extent KBC }\end{array}$ \\
\hline
\end{tabular}

NOTE: THIS TABLE CONTAINS A gATHERINg OF RESEARCH IDEAS AND NOT A COMPREHENSIVE RESEARCH AgENDA.

\section{BIBLIOGRAPHY}

AALBERS M. (2008), 'The Financialization of Home and the Mortgage Market Crisis', Competition \& Change, 12, pp. 148-166.

AALBERS M. (2012), Subprime Cities The Political Economy of Mortage Markets, Oxford, WilleyBlackwell.

AALBERS M. (2017), 'Corporate Financialization', in RICHARDSON D., CASTREE N., GOODCHILD M.F., KOBAYASHI A.L. \& MARSTON R. (eds.), The International Encyclopedia of Geography: People, the Earth, Environment, and Technology, Oxford, Wiley.

ALLEN J., PRYKE M. (2013), 'Financialising Household Water: Thames Water, MEIF, and "RingFenced" Politics', Cambridge Journal of Regions, Economy and Society, 6, pp. 419-439.

ANDERSON T., LEE E., THEODOSOPOULOS G., PING YIN Y. \& HASLAM C. (2014), 'Accounting for the financialized UK and US national business model', Critical Perspectives on Accounting, 25, pp. 78-91.

ARDAEN B. (2012), Tijdbom Dexia, de inside Story, Gent, Drukkerij nieuw Goff. 
ASHTON P., DOUSSARD M. \& WEBER R. (2016), 'Reconstituting the State: City Powers and Exposures in Chicago's Infrastructure Leases', Urban Studies, 53, pp. 1384-1400.

BASSENS D., ENGELEN E., DERUDDER B. \& WITLOX F. (2013), 'Securitization across Borders: Organizational Mimicry in Islamic Finance', Journal of Economic Geography, 13, pp. 85-106.

BASSENS D., VAN MEETEREN M. (2014), 'World Cities under Conditions of Financialized Globalization: Towards an Augmented World City Hypothesis', Progress in Human Geography, 39, pp. 1-24.

BRENNER N., PECK J. \& THEODORE N. (2010), 'Variegated Neoliberalization: Geographies, Modalities, Pathways', Global Networks, 10, pp. 182-222.

BROWN A. PASSARELLA M. \& SPENCER D. (2014), 'Financialisation, Economy, Society and Sustainable Development', FESSUD Working Papers, pp. 1-74.

BUYST E. (2011), 'Continuity and Change in Regional Disparities in Belgium during the Twentieth Century', Journal of Historical Geography, 37, pp. 329-337.

CHANG M., JONES E. (2013), 'Belgium and the Netherlands: Impatient Capital', in HARDIE I., HOWARTH D. (eds.), Market-Based Banking and the International Financial Crisis, Oxford, Oxford University Press, pp. 79-102.

CHRISTOPHERS B. (2015), 'The Limits to Financialization', Dialogues in Human Geography, 5, pp. 183-200.

DAEMS H. (1998), De Paradox van Het Belgische Kapitalisme, Tielt, Lannoo.

DAMEN S., VASTMANS F. \& BUYST E. (2016), 'The Effect of Mortgage Interest Deduction and Mortgage Characteristics on House Prices', Journal of Housing Economics, 34, pp. 15-29.

DEEG R., HARDIE I. \& MAXFIELD S. (2016), 'What Is Patient Capital, and Where Does It Exist?', Socio-Economic Review, 14, pp. 615-625.

DEPUYDT P. (2010), De Kloof: Hoe de Breuk Tussen Belgen En Nederlanders Fortis Fataal Werd, Amsterdam/Rotterdam, Prometheus/NRC Boeken.

DERUYTTER L., BASSENS D. (2017), The financialization of the Belgian local state: intermunicipal companies as shadow banks, Boston, AAG 2017.

DERUYTTER L., DERUDDER B. (under review), 'Keeping financialisation under the radar: Brussels Airport, Macquarie Bank and the Belgian politics of financialised infrastructure', Urban Studies.

DIXON A. (2011), 'Variegated Capitalism and the Geography of Finance: Towards a Common Agenda', Progress in Human Geography, 35, pp. 193-210.

DIXON A., MONK A. (2014), 'Frontier Finance', Annals of the Association of American Geographers, 104, pp. 852-868.

ENGELEN E. (2008), ‘The Case for Financialization', Competition \& Change, 12, pp. 111-119.

ERTURK I., FROUD J., SOLARI S. \& WILLIAMS K. (2005), 'The Reinvention of Prudence: Household Savings, Financialisation and Forms of Capitalism', CRESC Working Paper Series, 11.

EUROSTAT (2016), Online database, http://ec.europa.eu/eurostat/data/database.

FERNANDEZ R., AALBERS M. (2016), 'Financialization and Housing: Between Globalization and Varieties of Capitalism', Competition \& Change, 20, pp. 1-20.

FERNANDEZ R., HOFMAN A. \& AALBERS M.B. (2016), 'London and New York as a Safe Deposit Box for the Transnational Wealth Elite', Environment and Planning A, 48, pp. 2443-2461. 
FRENCH S., LEYSHON A. \& WAINWRIGHT T. (2011), 'Financializing Space, Spacing

Financialization', Progress in Human Geography, 35, pp. 798-819.

FROUD J., JOHAL S., LEAVER A. \& WILLIAMS K. (2006), Financialization and Strategy: Narrative and Numbers, London, Routledge.

GONZALEZ S., OOSTERLYNCK S. (2014), 'Crisis and Resilience in a Finance-Led City: Effects of the Global Financial Crisis in Leeds', Urban Studies, 51, pp. 3164-3179.

GOTHAM K. (2014), 'Re-Anchoring Capital in Disaster-Devastated Spaces: Financialisation and the Gulf Opportunity (GO) Zone Programme', Urban Studies, 53, pp. 1362-1383.

HARDIE I., HOWARTH D. (2013), Market-Based Banking and the International Financial Crisis, Oxford, Oxford University Press.

HARMES A. (1998), 'Institutional Investors and the Reproduction of Neoliberalism', Review of International Political Economy, 5, pp. 92-121.

HENDRIKSE R. (2015), The Long Arm of Finance, Amsterdam, Offpage.

HUESKES M., KOPPEJAN J. \& VERWEIJ S. (2016), 'Publiek-Private Samenwerking in Nederland en Vlaanderen: Een Review van Veertien Proefschriften', Bestuurskunde, 25, pp. 90-104.

KESTELOOT C., MAESSCHALCK F. DE (2001), 'Anti-Urbanism in Flanders: The Political and Social Consequences of a Spatial Class Struggle Strategy’, Belgeo, 1-2, pp. 41-62.

KRIPPNER G. (2005), 'The Financialization of the American Economy', Socio-Economic Review, 3, pp. 173-208.

LAGNA A. (2015), 'Derivatives and the Financialisation of the Italian State', New Political Economy, 21, pp. 167-186.

LAPAVITSAS C. (2009), 'Financialised Capitalism: Crisis and Financial Expropriation', Historical Materialism, 17, pp. 114-148.

LAPAVITSAS C., POWELL J. (2013), 'Financialisation Varied: A Comparative Analysis of Advanced Economies', Cambridge Journal of Regions, Economy and Society, 6, pp. 359-379.

LEHRER M., CELO S. (2016), 'German Family Capitalism in the $21^{\text {st }}$ Century: Patient Capital Between Bifurcation and Symbiosis', Socio-Economic Review, 14, pp. 729-750.

LOON J. VAN (2017a), The (Non-)Financialization of Urban Development in the Low Countries, PhD Dissertation, KU Leuven.

LOON J. VAN (2017b), ‘Geduldig versus Ongeduldig Kapitaal: Commerciële Projectontwikkeling in de Lage Landen', Ruimte \& Maatschappij, 8, pp. 10-32.

LOON J. VAN (2016), 'Patient versus Impatient Capital: The (Non-)Financialization of Real Estate Developers in the Low Countries', Socio-Economic Review, 14, pp. 709-728.

LOON J. VAN, AALBERS M.B. (2017), 'How Real Estate Became “Just Another Asset Class”: The Financialization of the Investment Strategies of Dutch Institutional Investors', European Planning Studies, 25, pp. 221-240.

LOON J. VAN, OOSTERLYNCK S. \& AALBERS M. (under review), Urban governance in the Low Countries; from Keynesian urban development towards entrepreneurial and financialized forms?

MARTIN R. (2002), Financialization of Daily Life, Philadelphia, Temple University.

MCKENZIE R.A. (2013), Determinants of Financialisation in South Africa: A Balance Sheet Approach (unpublished draft). 
MOLLY V., LAVEREN E. \& JORISSEN A. (2012), 'Intergenerational Differences in Family Firms: Impact on Capital Structure and Growth Behavior', Entrepreneurship: Theory and Practice, 36, pp. 703-725.

MOULAERT F., WILLEKENS F. (1985), Decentralization in Industrial Policy in Belgium towards a New Economic Feudalism?, Baltimore, John Hopkins European center for regional planning and research.

NACZYK M. (2012), 'Agents of Privatization? Business Groups and the Rise of Pension Funds in Continental Europe', Socio-Economic Review, 11, pp. 441-469.

OECD (2016), Online database, https://www.oecd.org/finance.

OOSTERLYNCK S. (2007), The Political Economy of Regionalism in Belgium: Imagining and Institutionalising the Flemish Regional Economy, PhD Thesis, Lancaster, Lancaster University.

OOSTERLYNCK S. (2010), 'Regulating Regional Uneven Development and the Politics of Reconfiguring Belgian State Space', Antipode, 42, pp. 1151-1179.

POULLET G. (2013), 'Het onroerend vermogen per institutionele sector', NBB, Economische Tijdschrift, juni, pp. 85-100.

PECK J., WHITESIDE H. (2016), 'Financializing Detroit', Economic Geography, 92, pp. 235-286.

PIKE A., POLLARD J. (2009), 'Economic Geographies of Financialization', Economic Geography, 86, pp. 29-51.

PRYKE M., ALLEN J. (2000), 'Monetized Time-Space: Derivatives - Money’s “New Imaginary”?', Economy and Society, 29, pp. 264-284.

ROMAINVILLE A. (2017), 'The Financialization of Housing in Brussels', International Journal of Urban and Regional Research (in print).

SAEY P., KESTELOOT C. \& VANDERMOTTEN C. (1998), 'Unequal Economic Development at the Origin of the Federalization Process', in Nationalism in Belgium, Palgrave Macmillan.

SWYNGEDOUW E. (2004), “The Mammon Quest: “Glocalization”, Interspatial Competition and the Monetary Order: The Construction of New Scales', in DUNFORD M., KAFKALIS G., Cities and Regions in the New Europe, London, Belhaven Press.

VANNESTE D., CABUS P. (2007), 'Networks of firms in Flanders, Belgium, Characteristics and territorial impacts', in PELLENBARG P., WEVER E. (eds.), International Business Geography, Case studies of corporate firms, Oxon, Routledge, pp. 23-60.

VANTHILLO T., VERHETSEL A. (2012), 'Paradigm change in regional policy: towards smart specialisation? Lessons from Flanders (Belgium) ', Belgeo, 1-2, pp. 1-16.

WARD C., LOON J. VAN \& WIJBURG G.J. (n.d.), Economic Transformation in the Balance: A Comparative Balance Sheet Analysis of Financialisation in Germany, the Netherlands and the UK (under review).

WEBER R. (2010), ‘Selling City Futures: The Financialization of Urban Redevelopment Policy’, Economic Geography, 86, pp. 251-274.

WINTERS S., BROECK K. VAN DEN (2016), 'Milestones in 25 Years of Housing Finance in Belgium', in LUNDE J., WHITEHEAD C. (eds.), Milestones In European Housing Finance, Chichester, WileyBlackwell, pp. 75-93.

WOJCIK D. (2012), 'The End of Investment Bank Capitalism? An Economic Geography of Financial Jobs and Power', Economic Geography, 88, pp. 345-368. 
ZWAN N. VAN DEN (2014), 'Making Sense of Financialization', Socio-Economic Review, 12, pp. 99-

129.

\section{NOTES}

1. The idea to quantitatively explore the financialisation of political economies through balance sheets arose during a collective research project with Callum Ward and Gertjan Wijburg: see Ward et al. (n.d.) and is inspired by Ertürk et al. (2005). Accordingly, many elements of this paper resonate with Ward et al. (n.d.) that also includes a more extensive discussion of the methodology.

\section{ABSTRACTS}

A quantitative screening shows that since the 1990s the financial assets and liabilities of important actors of the Belgian political economy have grown considerably. Whereas in other countries this growth of the financial sphere has been related to a transformation in capitalism in which 'finance' becomes dominant - i.e., the rise of financialized capitalism - Belgian scholarship on 'financialization' is scarce. Therefore, this paper offers a first exploration on the ways in which financialization could be observable in Belgium and consequently could be reshaping its economic geography. Accordingly, the paper offers both an introduction on financialization in Belgium and inspiration for debate and further research for geographers studying (elements of) the contemporary economic geography of Belgium.

Een kwantitatieve verkenning laat zien dat sinds de jaren ' 90 financiële bezittingen en verplichtingen van belangrijke domeinen binnen de Belgische politieke economie fors gegroeid zijn. Waar deze groei in andere landen gerelateerd wordt aan een transformatie binnen het kapitalistische systeem waarin 'finance' dominant wordt, m.a.w. de opkomst van het gefinancialiseerd kapitalisme, is in België onderzoek naar 'financialisering' schaars. Deze paper biedt daarom een eerste verkenning naar processen van financialisering in België en hun potentiële invloed op de Belgische economische geografie. Op die manier vormt deze paper zowel een introductie over financialisering in België en levert de paper voer voor discussie (over toekomstig onderzoek) voor geografen die (elementen van) de hedendaagse economische geografie van België onderzoeken.

\section{INDEX}

Keywords: financialized capitalism, financialization, Belgium, economic geography, political economy

Trefwoorden gefinancialiseerd kapitalisme, financialisering, België, economische geografie, politieke economie 


\section{AUTHOR}

\section{JANNES VAN LOON}

Jannes Van Loon completed his PhD dissertation at Division of Geography and Tourism, University of Leuven - KUL in June 2018. He is currently working as researcher at CBRE, jannes.vanloon@cbre.com 